University of Montana

ScholarWorks at University of Montana

$12-2004$

\title{
Soil Biota Facilitate Exotic Acer Invasions in Europe and North America
}

Kurt O. Reinhart

Ragan M. Callaway

University of Montana - Missoula, Ray.Callaway@mso.umt.edu

Follow this and additional works at: https://scholarworks.umt.edu/biosci_pubs

Part of the Biology Commons

Let us know how access to this document benefits you.

\section{Recommended Citation}

Reinhart, Kurt O. and Callaway, Ragan M., "Soil Biota Facilitate Exotic Acer Invasions in Europe and North America" (2004). Biological Sciences Faculty Publications. 221.

https://scholarworks.umt.edu/biosci_pubs/221

This Article is brought to you for free and open access by the Biological Sciences at ScholarWorks at University of Montana. It has been accepted for inclusion in Biological Sciences Faculty Publications by an authorized administrator of ScholarWorks at University of Montana. For more information, please contact

scholarworks@mso.umt.edu. 


\title{
SOIL BIOTA FACILITATE EXOTIC ACER INVASIONS IN EUROPE AND NORTH AMERICA
}

\author{
Kurt O. Reinhart ${ }^{1,2}$ and Ragan M. Callaway ${ }^{1}$ \\ University of Montana, Division of Biological Sciences, Missoula, Montana 59812 USA
}

\begin{abstract}
The primary hypothesis for successful exotic plant invasions is that the invaders have escaped the specialist consumers that control them (Enemy Release Hypothesis). However, few studies have rigorously tested this assertion with biogeographical experiments or considered the effects of soil organisms. We tested the Enemy Release Hypothesis and the enhanced role of mutualisms by comparing density patterns of the North American Acer negundo and European A. platanoides trees in their native and nonnative ranges. Invaders that have escaped their natural enemies are predicted to attain greater densities in nonnative than native ranges. To determine whether interactions with soil biota could explain the population distributions observed in the field, we compared the effects of sterilized and nonsterilized soil associated with Acer and non-Acer trees in native and nonnative ranges on the growth of seedlings in the greenhouse.

In the field study, distances from focal trees to the nearest Acer conspecifics were 56$77 \%$ less in their nonnative ranges than in their native ranges. In the greenhouse experiment, the effect of soil biota also differed between native and nonnative ranges of Acers. Relative to sterilized controls, soil associated with conspecifics and heterospecifics from the native ranges decreased the total biomass and relative change in height of Acer seedlings by $35 \%$ and $40 \%$, respectively. Soil associated with conspecifics in the nonnative ranges decreased the biomass and relative change in height of Acer seedlings by $112 \%$ and 64\%, respectively; but the soil associated with heterospecifics in the nonnative ranges increased biomass and relative change in height of Acer seedlings by $13 \%$ and $37 \%$, respectively.

Our results suggest that invasion of Acers is enhanced by soil biota associated with dominant native species and that the soil biota effect becomes more inhibitory as the Acers establish. The relative difference in soil biota effects between ranges supports the Enemy Release Hypothesis but also suggests that mutualists are relatively more beneficial to Acers in their nonnative ranges than in their native ranges. Mutualisms may be relatively more beneficial in nonnative ranges because the invader has escaped from the negative effect of natural enemies that may attenuate the positive effect of mutualists.
\end{abstract}

Key words: Acer negundo; Acer platanoides; Enemy Release Hypothesis; facilitation; invasive species; mutualisms; plant-soil biota interactions; soil biota effects.

\section{INTRODUCTION}

Understanding the rapid proliferation of invasive species that are introduced into new regions of the world is one of the most important and difficult problems in ecology. Some invasive species pose a threat to global biodiversity (Usher 1988, Mack et al. 2000, Pimentel et al. 2000) but the relative success of particular species is neither predictable nor mechanistically uniform (Mack et al. 2000). One of the leading hypotheses explaining the invasive success of nonnative species is the Enemy Release Hypothesis (Keane and Crawley 2002). This hypothesis contends that species proliferate in nonnative habitats because they have escaped the natural enemies that control them. In other words, the invaders experience fewer herbivores and

Manuscript received 2 July 2003; revised 6 March 2004; accepted 17 March 2004. Corresponding Editor: J. Gulledge.

${ }^{2}$ Present address: Indiana University, Department of Biology, Jordan Hall Room 127, 1001 East $3^{\text {rd }}$ Street, Bloomington, Indiana 47405-3700 USA.

E-mail: kureinha@indiana.edu pathogens in their nonnative ranges than in their native ranges. The Enemy Release Hypothesis is derived from the Janzen-Connell Hypothesis for population regulation in natural systems, which posits that interactions with herbivores, parasites, and pathogens limit the local density of species producing density-dependent interactions (Janzen 1970, Connell 1971). Although the Enemy Release Hypothesis is based on sound ecological theory and long-standing logic (e.g., Darwin 1859) and is the central underpinning of biological control theory (Lawton 1990, Murdoch and Briggs 1996), it has been subjected to few rigorous empirical tests (Maron and Vilá 2001).

The Enemy Release Hypothesis remains controversial because there have been only a small number of descriptive, correlative, and experimental examinations comparing biogeographical differences in antagonist richness and/or effect (Maron and Vilá 2001). However, these studies suggest that fewer natural enemies are present in invaded ranges than in natural ranges (Memmott et al. 2000, Wolfe 2002, Mitchell and Power 2003, 
but see Beckstead and Parker 2003). Only a few experiments have explicitly compared the effects of competitors (Callaway and Aschehoug 2000), pathogens (Beckstead and Parker 2003), parasites, or herbivores (DeWalt et al. 2004) on the same plant in its native and nonnative ranges. Moreover, discussion of this topic (Maron and Vilá 2001, Keane and Crawley 2002) and studies testing the Enemy Release Hypothesis (Memmott et al. 2000, Wolfe 2002, Mitchell and Power 2003) have focused primarily on interactions occurring aboveground (but see Beckstead and Parker 2003, Reinhart et al. 2003, Callaway et al. 2004); however, belowground interactions can be important determinants of plant community structure (Van Der Heijden et al. 1998, Klironomos 2002) and warrant investigation relative to the Enemy Release Hypothesis.

Recent studies have demonstrated dynamic feedbacks between plants and associated soil biota (Florence 1965, Augspurger and Kelly 1984, Van der Putten et al. 1993, Mills and Bever 1998, Eom et al. 2000, Packer and Clay 2000, Bever 2003). The direction of these feedbacks can be positive, negative, or neutral. The direction of the feedback depends on the relative negative effects of accumulating soilborne pathogens, herbivores, and parasites (Brown and Gange 1989, Van der Putten 2001) vs. the positive effects of accumulating mycorrhizal fungi, nitrogen-fixing bacteria, and other beneficial soil organisms (Allen and Allen 1984, Baker and Schwintzer 1990, Garbaye 1994), and the indirect effect of these plant-soil biota interactions on plant-plant interactions (Bever 2003). Negative soil community feedbacks appear to predominate in natural systems, and they provide density-dependent regulation of expanding populations and help to maintain plant species diversity (Florence 1965, Augspurger and Kelly 1984, Van der Putten et al. 1993, Mills and Bever 1998, Packer and Clay 2000, Klironomos 2002, Bever 2003). In natural systems, tree species can be negatively affected by host-specific organisms in the soil (Florence 1965, Augspurger and Kelly 1984, Mazzola 1998, Packer and Clay 2000). Negative feedbacks develop from the direct negative effects of host-specific pathogens (Mills and Bever 1998, Klironomos 2002) and the indirect positive effects of host-specific bacteria and mycorrhizae associated with other species relative to the effects of the focal species' mutualists (Westover and Bever 2001, Bever 2002). Indirect positive effects have been shown to occur when the mutualist community that develops in association with one species is actually more beneficial to another species (refer to Bever 2002 for further discussion). Direct positive feedbacks between soil biota and plants have been demonstrated, although they are less commonly observed in natural systems than negative feedbacks (Bever et al. 1997, Klironomos 2002). Although rare in natural systems, positive soil community feedbacks may facilitate plant invasions (Vitousek et al. 1987, Klironomos 2002, Vogelsang 2002, Reinhart et al.
2003, Callaway et al. 2004). Hence, the invasiveness of some plant species may be enhanced by escaping from harmful soil biota in their native ranges as well as by positive interactions with soil biota in their nonnative ranges.

We tested the Enemy Release Hypothesis and the enhanced role of mutualisms by performing a crosscontinental comparison of density patterns and effect of the soil biota on the North American box elder (Acer negundo L.) and European Norway maple (A. platanoides L.) in their native and nonnative ranges (each species has invaded the other's continent). The reciprocal design of this study enabled us to factor out sitespecific effects that generally enhance or inhibit growth of the focal species. Both species are known to form mycorrhizal associations (Brundrett et al. 1990, Verkade 1991). To help determine if Acers escaped from natural enemies, we compared density patterns in native and nonnative ranges and predicted local densities would be greater in nonnative ranges. To determine whether plant-soil biota interactions could explain the population structure data, we compared the effects of sterilized and nonsterilized soil from different sources (Acer vs. non-Acer trees) and ranges (native vs. nonnative). Thus, we predicted host-specific organisms from the native ranges of these Acer species would have a negative effect on the growth of Acer seedlings, while soil biota from the nonnative range would have a more positive effect on seedling growth, which would support the idea that Acers in nonnative ranges have escaped from belowground enemies in their native ranges but benefit from generalist mutualists (i.e., arbuscular mycorrhizal fungi).

\section{Methods}

\section{Site description}

We sampled Acer negundo soils and spatial patterns near the center of its native distribution in Madison, Wisconsin $\left(43^{\circ} 3.047^{\prime} \mathrm{N}, 89^{\circ} 22.241^{\prime} \mathrm{W}\right.$; Schmucker 1942). This site was dominated by Fraxinus pennsylvanica and $A$. saccharum. We sampled $A$. negundo in its invaded range in mesic deciduous riparian forests of the Rhône River near Sablons, France $\left(45^{\circ} 19.0^{\prime} \mathrm{N}\right.$, $4^{\circ} 46.0^{\prime}$ E) where Populus species are the dominant natives.

Acer platanoides naturally occurs in late-seral riparian communities and mesic deciduous forests throughout much of Europe (Schmucker 1942). We collected soil and measured densities in its native range in France. We collected an equal number of subsamples in a riparian forest on the Rhône River near Sablons $\left(45^{\circ} 19.0^{\prime} \mathrm{N}, 4^{\circ} 46.0^{\prime} \mathrm{E}\right)$ and in a mesic deciduous forest near Séchilienne, France $\left(45^{\circ} 4.0^{\prime} \mathrm{N}, 5^{\circ} 49.6^{\prime} \mathrm{E}\right)$. These forests were dominated by Fraxinus excelsior. We also sampled A. platanoides at two sites in its invaded range in the United State. The first site was a $3-5 \mathrm{~km}$ corridor of riparian forest of the Rattlesnake Creek, Missoula, 
Montana. We collected an equal number of subsamples from three preserves along the Rattlesnake Creek including: Greenough Park (46 52.644' N, 113 58.565' W), Tom Greene Memorial Park (46 53.416' N, $\left.113^{\circ} 58.254^{\prime} \mathrm{W}\right)$, and Bugbee Park (46 52.998' N, $\left.113^{\circ} 58.273^{\prime} \mathrm{W}\right)$. These riparian areas were composed of mixed deciduous forests dominated by the natives Populus trichocarpa and Pinus ponderosa. The second site where we sampled A. platanoides in its nonnative range was in late-successional forests in New Jersey. We collected an equal number of subsamples from the Drew Forest Preserve, Drew University $\left(40^{\circ} 45.0^{\prime} \mathrm{N}\right.$, $\left.74^{\circ} 25.0^{\prime} \mathrm{W}\right)$ and the Hutcheson Memorial Forest $\left(40^{\circ} 30.157^{\prime} \mathrm{N}, 74^{\circ} 34.310^{\prime} \mathrm{W}\right)$. Each of these forests was dominated by the natives Fagus grandifolia and A. saccharum.

\section{Nearest neighbor measurements}

At all sites (France, Montana, New Jersey, and Wisconsin), we measured the distances from randomly chosen $A$. negundo or A. platanoides trees in the canopy to the three nearest conspecific trees $\geq 2 \mathrm{~m}$ in height. If neighboring conspecific trees were not found within $50-55 \mathrm{~m}$ of the focal tree, then the distances to the nearest neighbors were conservatively (because distances in native sites were often much longer than 50 $\mathrm{m})$ recorded at $50 \mathrm{~m}$. The distances to the nearest three neighbors were averaged, and we tested the effect of range (native vs. nonnative) and species of Acer on average distance to the nearest conspecific using twoway ANOVA with SPSS version 10 (SPSS 2000).

\section{Effect of soil biota}

A greenhouse experiment was conducted to test the effect of soil from different ranges (native vs. nonnative), soil biota (nonsterile vs. sterile), and soil from different tree species (conspecific vs. heterospecific) on the growth of Acer negundo and Acer platanoides seedlings $(n=12$ seedlings started per treatment combination). This experiment utilized soil from the native (Wisconsin) and nonnative (France) ranges of $A$. negundo and from the native (France) and nonnative (Montana and New Jersey) ranges of $A$. platanoides. The soil for the A. negundo portion of the experiment was collected from the native range in Wisconsin $(n=$ 12 ) on 5 August 2001. In the nonnative range, soil was collected from Sablons, France $(n=12)$ from $26-29$ June 2001. In the native range of $A$. platanoides, soil was collected near Sablons and Séchilienne, France between 26 and 29 June ( $n=6$ per site). In the invaded range of A. platanoides, soil was collected from Drew Forest Preserve and Hutcheson Memorial Forest, New Jersey ( $n=6$ per site) on 2 July 2001 and from the three sites in Missoula, Montana ( $n=4$ per site) on 17 July 2001.

To compare the effects of soil source (conspecific vs. heterospecific) within a site, soil was collected beneath randomly selected target Acer trees and also be- neath the other dominant tree species at the site. NonAcer samples were collected $\geq 20 \mathrm{~m}$ from the target or any other $A$. negundo or A. platanoides trees. Other dominant species were Fraxinus pennsylvanica in the native range of $A$. negundo and $F$. excelsior in its invaded range. The native dominant species associated with A. platanoides include: Fraxinus excelsior in the native range in France, Populus trichocarpa in the invaded range in Montana, and Fagus grandifolia in the invaded range in New Jersey. We did not mix soil collected from different individual trees so we could use them as experimental replicates $(n=12$ per each site [France, Montana, New Jersey, and Wisconsin]). All soil was transported according to USDA specifications (Animal and Plant Health Inspection Service 1983) and guidelines established for R. M. Callaway's “Application for Permit to Receive Soil" by APHIS, USDA. Soil was shipped to Missoula, Montana and stored for a maximum of two weeks at room temperature in a growth chamber at the University of Montana.

All tools, materials, and surfaces coming in contact with nonsterile soil were sterilized to avoid cross contamination by one of five methods: autoclaving for $60-$ $180 \mathrm{~min}$, flame sterilization, surfaces sprayed or material soaked in $\geq 10 \%$ bleach solution (itself $5.25 \%$ aqueous $\mathrm{NaOCl}$ ), surfaces sprayed with $70 \% \mathrm{ETOH}$ solution, or material heated at $\geq 110^{\circ} \mathrm{C}$ for $\geq 16 \mathrm{~h}$ in a drying oven. All of the field soil was prepared by dicing the roots and crumbling the soil until it passed through a $1-\mathrm{cm}^{2}$ opening in a mesh sieve. Soil aliquots of 125 and $25 \mathrm{~mL}$ were removed from each replicate within a region and then double autoclaved to kill all soil biota. The $25 \mathrm{~mL}$ of sterile field soil and $25 \mathrm{~mL}$ of the nonsterile field soil were used as inoculum for the sterilization treatments. Then $12125-\mathrm{mL}$ aliquots of the sterile soil from each region were combined into conspecific and heterospecific composites. The sterile soil composites were used to construct a sterile background soil for each pot to help control for fertility differences between conspecific and heterospecific soils and help dilute the fertility effect associated with sterilization treatments of the inoculum (see Troelstra et al. 2001 for discussion of fertilization effects). The background soil mixture totaled $\sim 2.5 \mathrm{~L}$ of sterile medium per pot. The sterile background mixture consisted of $50 \mathrm{~mL}$ of sterilized field soil with half from the conspecific composite and half from the heterospecific composite. The remaining portion $(\sim 97 \%)$ of background soil consisted of sterile (once autoclaved) commercial silica sand averaging $0.60-0.85 \mathrm{~mm}$ in diameter (20/30 grit, Lane Mountain Company, Valley, Washington, USA). Pots with a capacity of $\sim 2.5 \mathrm{~L}$ were filled with the sterile background soil and mixed with $25 \mathrm{~mL}(\sim 1 \%)$ of either sterile or nonsterile field soil inoculum $(n=$ 12 soil inoculum replicates per sterilization $\times$ source $\times$ species treatments) within each region (i.e., France, Montana, New Jersey, and Wisconsin). 
The experimental pots for the A. negundo portion of the experiment were planted with $A$. negundo seeds (purchased from Lawyers Nursery, Plains, Montana, USA) that were surface sterilized by placing the seeds into $5 \%$ bleach solution for $10 \mathrm{~min}$ and then rinsing the seeds with deionized water. The seedlings were thinned to one plant per pot after 30-60 d, depending on individual experiments, following the sowing of seed. The A. platanoides portion of the experiment could not be planted with seeds because of low germination. Instead, we planted A. platanoides seedlings of equal size, which germinated in 2001, collected on the University of Montana campus. We surface sterilized the roots in order to minimize transplanting soil biota from the field soil into the experimental units. The roots of each seedling were surface sterilized by submerging the roots in a solution of $5 \%$ bleach for 10 min and then thoroughly rinsing with dionized water. These experiments were started between July and August 2001. Seedlings that died within two weeks following planting were replaced.

The initial stem height of each seedling was measured at 30-60 d after the initiation of each regional experiment. Supplemental light was added in the autumn and winter, and shading was provided in the summer to ameliorate extreme temperatures and light intensities. To encourage the development of mycorrhizal symbioses, we applied low concentrations of nutrients (particularly with low relative concentrations of phosphorus) to the soils (Johnson et al. 1992, Smith and Read 1997). During 2002, plants were fertilized approximately once every two weeks with 100-110 mL/ plant of Scott's Miracle-Grow Excel (NPK ratio of 152-20, Scotts-Sierra Horticultural Products Company, Marysville, Ohio, USA) mixed at $0.171 \mathrm{~g} / \mathrm{L}$. In spring and summer 2002, the plants were also provided with $0.61 \mathrm{~mL}$ of Osmocote Outdoor and Indoor Slow Release Plant Food at monthly intervals (NPK ratio of 19-6-12, Scotts-Sierra Horticultural Products Company, Marysville, Ohio, USA) to provide a continuous supply of nutrients. All of the regional experiments were harvested from 24 to 31 August 2002, and each living seedling was measured for final height and the plants were harvested and divided into roots, stems, and leaves. All harvested material was dried at $65^{\circ} \mathrm{C}$ until constant mass.

We tested the effect of sites on the total biomass and relative change in seedling height ([(final height - initial height)/ initial height] $\times 100$ ) in the nonnative range (Montana and New Jersey) for A. platanoides with a three-way ANOVA (sites, soil biota, and soil sources). We found no effect of site and combined the A. platanoides data from Montana and New Jersey. This pooling allowed us to conduct three-way ANOVAs to test the effect of species (Acer negundo and A. platanoides), soil sterilization (sterile vs. nonsterile), and soil source (conspecific vs. heterospecific) on the total biomass and relative change in height for each range (na-
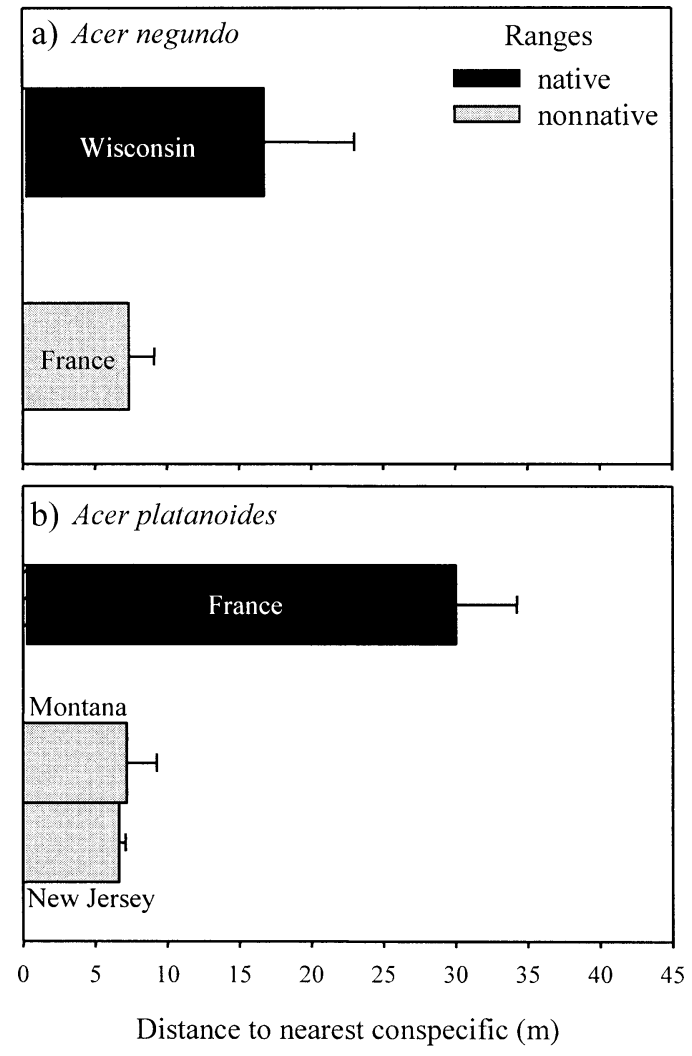

FIG. 1. Distances between conspecifics of (a) Acer negundo and (b) Acer platanoides in their native ranges (black bars) and their nonnative ranges (gray bars). The native range for A. negundo is Wisconsin ( $n=5$ trees); for A. platanoides the native range is France $(n=8)$. The nonnative site for $A$. negundo was in France $(n=4)$; for A. platanoides nonnative sites were Montana $(n=9)$ and New Jersey $(n=6)$. Refer to the Results section for statistical results. Bars represent the distance from randomly selected $A$. negundo and A. platanoides trees to the three nearest trees (mean $+1 \mathrm{SE}$ ).

tive and nonnative) using SPSS version 10 (SPSS 2000). To maintain homogeneity of variances for these analyses, we transformed data with either a square root function (square $\operatorname{root}[x+0.5])$ or $\log$ function $(\log [x$ $+1]$ ). The data for relative change in height continued to violate the assumption of homogeneity of variance following transformation (Levene's test; $F=2.27$, df $=7,76, P=0.037$ ), but no satisfactory transformation could be found. The analysis was still performed, because ANOVA is robust to heterogeneity of variances (Underwood 2002).

\section{RESULTS}

Overall, neighboring conspecifics were 56-77\% more closely spaced in nonnative than in native ranges (ANOVA; range, $F=10.60$, df $=1,32, P=0.003$; Fig. 1). There was no effect of species and range $X$ species on nearest neighbor distances (species, $F=$ 0.08 , df $=1,32, P=0.781$; range $\times$ species, $F=$ 1.37 , df $=1,32, P=0.252$ ). 
TABLE 1. Summary of three-way ANOVA of effects of tree species (Acer negundo and A. platanoides), soil sterilization (nonsterile vs. sterile soil), and soil source (conspecific vs. heterospecific) on total biomass and relative change in height of seedlings grown in soils from native ranges.

\begin{tabular}{|c|c|c|c|c|c|}
\hline $\begin{array}{l}\text { Source of } \\
\text { variation }\end{array}$ & $\begin{array}{c}\text { Dependent } \\
\text { variable }\end{array}$ & $\mathrm{df}$ & MS & $F$ & $P$ \\
\hline \multirow[t]{2}{*}{ Species } & biomass & 1,84 & 93.96 & 49.74 & $<0.0005$ \\
\hline & height & 1,84 & $7,843.09$ & 107.91 & $<0.0005$ \\
\hline \multirow[t]{2}{*}{ Sterilization } & biomass & 1,84 & 10.27 & 5.44 & 0.022 \\
\hline & height & 1,84 & 380.33 & 5.23 & 0.025 \\
\hline \multirow[t]{2}{*}{ Source } & biomass & 1,84 & 1.46 & 0.77 & 0.382 \\
\hline & height & 1,84 & 55.04 & 0.76 & 0.387 \\
\hline \multirow[t]{2}{*}{ Species $\times$ sterilization } & biomass & 1,84 & $<0.01$ & $<0.01$ & 0.949 \\
\hline & height & 1,84 & 0.87 & 0.01 & 0.913 \\
\hline \multirow[t]{2}{*}{ Species $\times$ source } & biomass & 1,84 & 0.53 & 0.28 & 0.599 \\
\hline & height & 1,84 & 9.43 & 0.13 & 0.720 \\
\hline \multirow[t]{2}{*}{ Sterilization $\times$ source } & biomass & 1,84 & 0.02 & 0.01 & 0.910 \\
\hline & height & 1,84 & 26.10 & 0.36 & 0.551 \\
\hline \multirow[t]{2}{*}{ Species $\times$ sterilization $\times$ source } & biomass & 1,84 & 0.03 & 0.01 & 0.906 \\
\hline & height & 1,84 & 0.16 & $<0.01$ & 0.963 \\
\hline \multirow[t]{2}{*}{ Error } & biomass & 1,84 & 1.89 & & \\
\hline & height & 1,84 & 72.68 & & \\
\hline
\end{tabular}

Notes: Tests were performed using the Type III sums of squares from SPSS version 10. Biomass and relative change in height data were transformed with a square-root function (square $\operatorname{root}[x+0.5]$ ). The data for Acer negundo were collected in Wisconsin, USA, and data for A. platanoides were collected in France.

Sterilization of soil from native communities had a more positive effect (negative effect of soil biota) on the growth of Acer seedlings than sterilization of the soil from the communities invaded by Acer species. In the native ranges of Acers, the soil biota decreased (positive effect of soil sterilization) total biomass of Acer seedlings by $35 \%$ and decreased relative change in height of seedlings by $40 \%$ (Table 1, Figs. 2 and 3 ). In contrast, in the nonnative ranges we identified an interactive effect of soil sterilization and soil source on the total biomass (Table 2, Fig. 2) and relative change in height of seedlings (Table 2, Fig. 3). In the nonnative ranges the soil biota associated with conspecifics decreased (positive effect of soil sterilization) the biomass and relative change in height by $112 \%$ and
$64 \%$, respectively; but unlike in the native ranges of Acer, soil biota associated with heterospecifics increased (negative effect of soil sterilization) seedling biomass (Fig. 2) and relative change in height (Fig. 3) of seedlings by $13 \%$ and $37 \%$, respectively. Overall, A. negundo grew more than A. platanoides seedlings (Tables 1 and 2, Figs. 2 and 3); however, there were no interactions between species and the other factors (Tables 1 and 2).

\section{DISCUSSION}

The Enemy Release Hypothesis is often invoked to explain the invasive success of nonnative species; however, few studies have rigorously tested this hypothesis with biogeographical experiments. By utilizing a cross-
FIG. 2. The effect of soil sterilization and soil source on total biomass of Acer negundo and $A$. platanoides seedlings grown in soil from their native and nonnative ranges. The native range for A. negundo was in Wisconsin $(n=12$ per treatment), and for $A$. platanoides the native range was in France $(n=8-10)$. The nonnative site for A. negundo was in France $(n=12)$; for A. platanoides, nonnative sites were Montana $(n=9-10)$ and New Jersey $(n=6-10)$. Refer to Tables 1 and 2 for ANOVA results. Bars represent the average total biomass $\pm 1 \mathrm{SE}$.
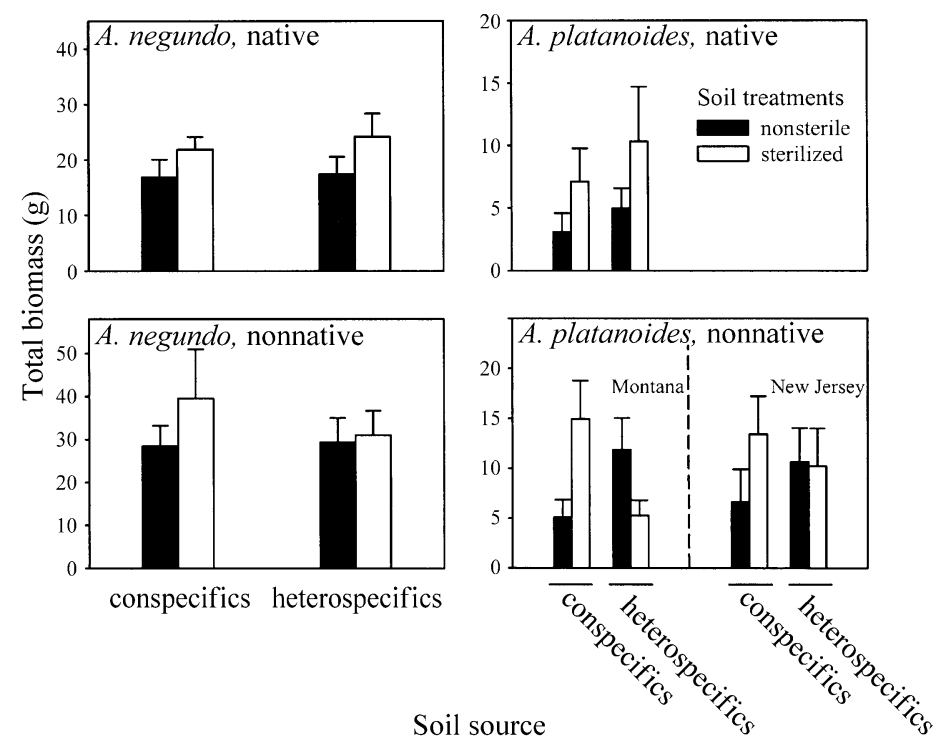

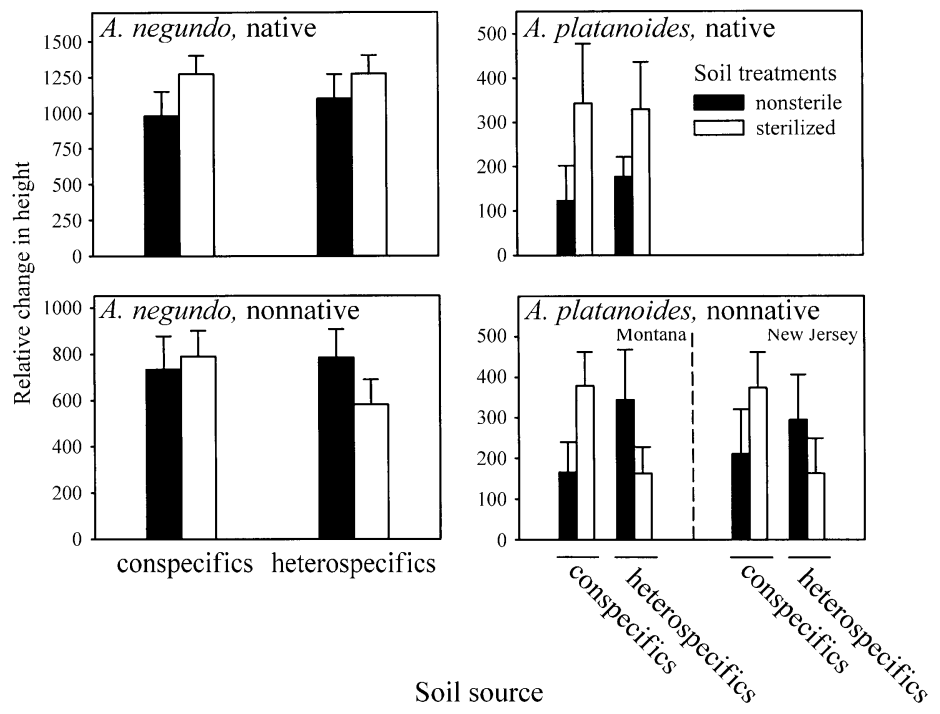

FIG. 3. The effect of soil sterilization and soil source on relative change in height of Acer negundo and A. platanoides seedlings grown in soil from their native and nonnative ranges. See the description provided for Fig. 2.

Soil source

continental experimental design linking density patterns in the field with plant-soil biota interactions gleaned from a greenhouse experiment, we were able to test the Enemy Release Hypothesis and enhanced role of mutualisms by comparing the population structure and plant-soil community interactions for Acers in their native and nonnative ranges. Our results show denser aggregations of conspecifics around focal Acer negundo and $A$. platanoides trees in nonnative than native ranges. This suggests Acers were less inhibited by intraspecific mechanisms of density- and/or distance-dependent regulation during the early stages of invasion. The greater density of Acers in nonnative than native ranges corresponds with the positive effect of the soil biota, relative to sterilized soil treatments, associated with heterospecific trees in the nonnative range relative to in the native range. However, soil biota associated with conspecifics had a negative effect on seedling growth in native and nonnative ranges.

Despite finding important effects of soil biota on Acers, in contrast to our hypothesis the negative hostspecific effects of the soil biota on seedling growth were not stronger in the native range than the nonnative range. In the native ranges, we hypothesized that both Acers would experience negative effects of the soil biota associated with conspecifics and neutral to positive effects of the soil biota associated with heterospecifics, since host-specific soil pathogens often accumulate in soils associated with individual plants in their native ranges (e.g., Packer and Clay 2000, Bever 2003). Although we did not find clear evidence for species-specific plant-soil biota feedbacks as described

TABLE 2. Summary of three-way ANOVA of effects of tree species (Acer negundo and A. platanoides), soil sterilization (nonsterile vs. sterile soil), and soil source (conspecific vs. heterospecific) on total biomass and relative change in height of seedlings grown in soils from nonnative ranges.

\begin{tabular}{|c|c|c|c|c|c|}
\hline Source of variation & $\begin{array}{c}\text { Dependent } \\
\text { variable }\end{array}$ & df & MS & $F$ & $P$ \\
\hline \multirow[t]{2}{*}{ Species } & biomass & 1,120 & 189.00 & 65.35 & $<0.0005$ \\
\hline & height & 1,120 & $3,180.00$ & 49.90 & $<0.0005$ \\
\hline \multirow[t]{2}{*}{ Sterilization } & biomass & 1,120 & 5.41 & 1.87 & 0.175 \\
\hline & height & 1,120 & 3.01 & 0.05 & 0.828 \\
\hline \multirow[t]{2}{*}{ Source } & biomass & 1,120 & 0.89 & 0.31 & 0.580 \\
\hline & height & 1,120 & 15.99 & 0.25 & 0.617 \\
\hline \multirow[t]{2}{*}{ Species $\times$ sterilization } & biomass & 1,120 & 0.06 & 0.02 & 0.885 \\
\hline & height & 1,120 & 66.17 & 1.04 & 0.310 \\
\hline \multirow[t]{2}{*}{ Species $\times$ source } & biomass & 1,120 & 0.62 & 0.22 & 0.644 \\
\hline & height & 1,120 & 14.12 & 0.22 & 0.639 \\
\hline \multirow[t]{2}{*}{ Sterilization $\times$ source } & biomass & 1,120 & 13.11 & 4.53 & 0.036 \\
\hline & height & 1,120 & 376.25 & 5.90 & 0.017 \\
\hline \multirow[t]{2}{*}{ Species $\times$ sterilization $\times$ source } & biomass & 1,120 & 2.74 & 0.95 & 0.333 \\
\hline & height & 1,120 & 21.13 & 0.33 & 0.566 \\
\hline \multirow[t]{2}{*}{ Error } & biomass & 112,120 & 2.90 & & \\
\hline & height & 112,120 & 63.73 & & \\
\hline
\end{tabular}

Notes: Tests were performed using the Type III sums of squares from SPSS version 10. Biomass and relative change in height data were transformed with a square-root function (square $\operatorname{root}[x+0.5]$ ). The data for Acer negundo were collected in France; data for A. platanoides were collected in Montana and New Jersey, USA. 
in the literature for natural systems (e.g., Mills and Bever 1998), we identified a net or regional negative effect of resident soil biota on growth regardless of soil source in the native ranges of Acers.

Interactions among Acer species and the soil biota from different sites and sources were more complex than predicted by the Enemy Release Hypothesis or observed in previous plant-soil community feedback studies. For example, Acer species appear to accumulate inhibitory soil biota even in their invaded range, but the positive effect of soil biota associated with heterospecifics in this range suggests that Acers benefit more from the soil biota distributed broadly in their nonnative than native ranges. Altogether, our findings suggest that the resident soil biota facilitate the spread and dominance of these species in their nonnative ranges relative to the suppressive effects of the soil biota in their native ranges. This does not preclude the role of other biogeographical differences in the abiotic environment (e.g., soil fertility) or biological interactions (e.g., competition), but the reciprocal design factors out site-specific effects, indicating that the pattern is generalizable for these two invasive Acer species.

In a study with major implications for exotic invasions, Klironomos (2002) found that invasive nonnative plants in North America experienced positive "soil feedback responses," while rare native species experienced negative soil feedbacks (Klironomos 2002). This variation in feedback responses for native vs. nonnative species is supportive of the Enemy Release Hypothesis. However, Klironomos also reported the soil feedback response of 61 species ( $\sim 27$ native species) that he related to each species' abundance. He found that most species experienced negative soil feedbacks, and that the abundances of individual species were positively correlated with their soil feedback responses. However, inspection of all 61 species suggests that nonnative species do not have clearly different directions of soil feedback than native species. In contrast, our results for two Acer species and results for two other plant species indicate that invaders are more negatively affected by the soil communities in their native ranges than in their nonnative ranges (Reinhart et al. 2003, Callaway et al. 2004).

The Enemy Release Hypothesis predicts that invasive species will benefit most by escaping from their host-specific enemies (Keane and Crawley 2002). Previous studies have reported a greater richness of specialist herbivores in native than nonnative ranges (Memmott et al. 2000) and found more negative plantsoil biota interactions in the native than invaded systems (Reinhart et al. 2003, Callaway et al. 2004). However, our results suggest Acers are being just as negatively affected by belowground organisms associated with conspecifics in their invaded ranges as in their native ranges. The fundamental difference between native and invaded ranges was the more positive effect of soil biota associated with heterospecifics in invaded ranges. Acers benefited from the soil biota associated with dominant heterospecifics, suggesting a positive effect of the native dominants on the invading Acers. Other studies have reported positive plant-soil feedbacks (Klironomos 2002) and more positive effects of the soil biota in invaded than native ranges (Reinhart et al. 2003, Callaway et al. 2004, but see Beckstead and Parker 2003).

The more positive effect of the soil biota associated with the soils of heterospecifics in the nonnative ranges relative to in native ranges that we report may contribute to the invasiveness of Acer negundo and $A$. platanoides, as suggested by the denser aggregations of conspecifics around Acers in nonnative than native ranges. Thus, the biogeographical variation in plantsoil biota interactions may help facilitate the establishment and spread of Acers in invaded forests relative to native forests. The contrasting results between conspecific and heterospecific soil sources indicate that negative soil feedbacks (i.e., density-dependent negative effects) eventually develop around Acers even in invaded regions. However, closer spacing of neighbors in the native than nonnative ranges suggests Acers were less inhibited by intraspecific mechanisms of densityand/or distance-dependent regulation during the early stages of invasion. In time, invasive plants may reacquire their natural enemies (Scheffer 2003) and/or acquire enemies already present in the invaded ranges. Thus, the strength and direction of the soil biota effect on successful invaders (not initially repelled by abiotic or biotic factors) is likely to transition from positive to negative over time. Alternatively, interactions not accounted for in our experiment may also affect the spatial distribution of $A$. negundo and A. platanoides.

Acer platanoides trees in riparian forests of the northern Rocky Mountains may indirectly facilitate conspecific seedlings by producing deeper shade than native canopy species and reducing the competitive effects of natives on exceptionally shade-tolerant $A$. platanoides seedlings (K. O. Reinhart, unpublished data). Furthermore, established A. platanoides appear to increase soil moisture in the understory, which may facilitate conspecific seedlings (Reinhart 2003). These effects of established adult trees may contribute substantially to the aggregation patterns observed in mixed deciduous and coniferous forests in Montana.

Plants in their nonnative ranges are often facilitated by soil biota (Vitousek et al. 1987, Marler et al. 1999, Callaway et al. 2001, Klironomos 2002), while native plant species are often negatively affected by the accumulation of host-specific portions of the soil biota (e.g., Klironomos 2002). Our results did not identify a switch from negative plant-soil community feedback in native ranges to positive plant-soil community feedback in nonnative ranges. Instead, we found a more complicated pattern with a general negative effect of the soil biota on the growth of Acers in their native ranges. The general negative effects of the soil com- 
munity on plants in their native ranges relative to the positive effects of the soil community associated with heterospecifics on plants in their nonnative ranges suggests that plant invasions may be facilitated at a regional scale by soil microbes and that this is supportive of the Enemy Release Hypothesis. However, the Enemy Release Hypothesis predicts that nonnative plants will benefit when they invade areas without the specialist enemies from their native ranges (Keane and Crawley 2002). Our results suggest that the negative effect of the soil biota in the native range is driven by generalist and/or host-specific organisms associated with conspecifics and generalist organisms associated with heterospecifics, while the negative effect in the nonnative range is driven by host-specific organisms associated with conspecifics. Understanding the net impact of enemies in native and nonnative ranges may be equal to or more important than the degree of specialization or species richness of pathogens. Our results are also for the net effect of the soil community on plant growth and not the isolated effect of soil-borne enemies. The biogeographical differences in soil biota effects that we observe may also be attributed to mutualists having more positive effects on Acers in their nonnative than their native ranges. Also, there may be important shifts in these interactions within ranges as described in another study (Callaway et al. 2004) that are not resolved by the limited coverage used in our experiment relative to the entire distribution of these species.

Improved understanding of plant-soil interactions (e.g., identity of pathogens, effect of pathogens, broader scale description of interactions, and pathogen host specificity) in nonnative ranges relative to native ranges will help resolve whether the invaders have escaped from belowground enemies or adopted better mutualists in their nonnative ranges relative to their native ranges. Our results suggest that biogeographical variation in the strength of belowground interactions among plants and soil biota may play an important role in the invasion of nonnative plant species. Thus, consideration of above- and belowground enemies is likely to improve our understanding of biological invasions, which may involve release from natural enemies, as well as enhanced positive interactions with mutualists.

\section{ACKNOWLEDGMENTS}

We thank Adam Collins and Giles Thelen for their assistance with the greenhouse experiments. We also thank Julie and Ronald Reinhart and Laurie Callaway for their assistance with fieldwork in New Jersey and France. We thank Matthias Rillig for his helpful discussions and two anonymous reviewers for their comments. We are also grateful to several people and organizations for providing assistance in identifying sites and gaining access to sites in France, Montana, and New Jersey. This includes: Richard Michalet and Didier Joud from University Joseph Fourier, Grenoble, France; Bernard Pont from Réserve Naturelle de l' île de la Platière, Sablons, France; Sara Webb from Drew University, New Jersey; Drew Forest Preserve; Ted Stiles, Hutcheson Memorial Forest, New Jersey; and Greenough, Bugbee, and Tom Greene Memorial Parks, Montana. This research was supported in part by funding to K. O. Reinhart by the Bertha Morton Scholarship and John W. Marr Ecology Grant and to R. M. Callaway by the Andrew W. Mellon Foundation and the National Science Foundation (DEB-9726829 and the NSF International Programs).

\section{Literature Cited}

Allen, E. B., and M. F. Allen. 1984. Competition between plants of different successional stages: mycorrhizae as regulators. Canadian Journal of Botany 62:2625-2629.

Animal and Plant Health Inspection Service. 1983. Safeguard guidelines for containment of plant pests under permit. APHIS 81-61 pages 1-12. United States Department of Agriculture, Washington, D.C., USA.

Augspurger, C. K., and C. K. Kelly. 1984. Pathogen mortality of tropical tree seedlings: experimental studies of the effects of dispersal distance, seedling density, and light conditions. Oecologia 61:211-217.

Baker, D. D., and C. R. Schwintzer. 1990. Introduction. Pages 1-13 in D. R. Schwintzer and J. D. Tjepkema, editors. The biology of Frankia and actinorhizal plants. Academic Press, San Diego, California, USA.

Beckstead, J., and I. M. Parker. 2003. Invasiveness of Ammophila arenaria: release from soil-borne pathogens? Ecology 84:2824-2831.

Bever, J. D. 2002. Negative feedback within a mutualism: host-specific growth of mycorrhizal fungi reduces plant benefit. Proceedings of the Royal Society of London 269: 2595-2601.

Bever, J. D. 2003. Soil community feedback and the coexistence of competitors: conceptual frameworks and empirical tests. New Phytologist 157:465-473.

Bever, J. D., K. M. Westover, and J. Antonovics. 1997. Incorporating the soil community into plant population dynamics: the utility of the feedback approach. Journal of Ecology 85:561-573.

Brown, V. K., and A. C. Gange. 1989. Herbivory by soildwelling insects depresses plant species richness. Functional Ecology 3:667-671.

Brundrett, M., G. Murase, and B. Kendrick. 1990. Comparative anatomy of roots and mycorrhizae of common Ontario trees. Canadian Journal of Botany 68:551-578.

Callaway, R. M., and E. T. Aschehoug. 2000. Invasive plants versus their new and old neighbors: a mechanism for exotic invasion. Science 290:521-523.

Callaway, R. M., B. Newingham, C. A. Zabinski, and B. E. Mahall. 2001. Compensatory growth and competitive ability of an invasive weed are enhanced by soil fungi and native neighbours. Ecology Letters 4:429-433.

Callaway, R. M., G. Thelen, A. Rodriguez, and W. E. Holben. 2004. Soil biota and exotic plant invasion. Nature 427: 731-733.

Connell, J. H. 1971. On the role of natural enemies in preventing competitive exclusion in some marine animals and in rain forests. Pages 298-312 in P. J. den Boer and G. R. Gradwell, editors. Dynamics in populations. Center for Agricultural Publishing and Documentation, Wageningen, The Netherlands.

Darwin, C. 1859. The origin of species by means of natural selection. William Benton, London, UK.

DeWalt, S. J., J. S. Denslow, and K. Ickes. 2004. Naturalenemy release facilitates habitat expansion of the invasive tropical shrub Clidemia hirta. Ecology 85:471-483.

Eom, A. H., D. C. Hartnett, and G. W. T. Wilson. 2000. Host plant species effects on arbuscular mycorrhizal fungal communities in tallgrass prairie. Oecologia 122:435-444.

Florence, R. G. 1965. Decline of old-growth redwood forests in relation to some soil microbiological processes. Ecology 46:52-64. 
Garbaye, J. 1994. Tansley review no. 76 helper bacteria: a new dimension to the mycorrhizal symbiosis. New Phytologist 128: 197-210.

Janzen, D. H. 1970. Herbivores and the number of tree species in tropical forests. American Naturalist 104:501-528.

Johnson, N. C., D. Tilman, and D. Wedin. 1992. Plant and soil controls on mycorrhizal fungal communities. Ecology 73:2034-2042.

Keane, R. M., and M. J. Crawley. 2002. Exotic plant invasions and the enemy release hypothesis. Trends in Ecology and Evolution 17:164-170.

Klironomos, J. N. 2002. Feedback with soil biota contributes to plant rarity and invasiveness in communities. Nature 417:67-70.

Lawton, J. H. 1990. Biological control of plants: a review of generalisations, rules, and principles using insects as agents. Pages 3-17 in C. Bassett, L. J. Whitehouse, and J. A. Zabkiewicz, editors. Proceedings of an International Conference, Rotorua, New Zealand FRI Bulletin 155. New Zealand Ministry of Forestry, Rotorua, New Zealand.

Mack, R. N., D. Simberloff, W. M. Lonsdale, H. Evans, M. Clout, and F. A. Bazzaz. 2000. Biotic invasions: causes, epidemiology, global consequences, and control. Ecological Applications 10:689-710.

Marler, M. J., C. A. Zabinski, and R. M. Callaway. 1999. Mycorrhizae indirectly enhance competitive effects of an invasive forb on a native bunchgrass. Ecology 80:11801186.

Maron, J. L., and M. Vilá. 2001. When do herbivores affect plant invasion? Evidence for the natural enemies and biotic resistance hypotheses. Oikos 95:361-373.

Mazzola, M. 1998. Elucidation of the microbial complex having a causal role in the development of apple replant disease in Washington. Phytopathology 88:930-938.

Memmott, J., S. V. Fowler, Q. Paynter, A. W. Sheppard, and P. Syrett. 2000. The invertebrate fauna on broom, Cytisus scoparius, in two native and two exotic habitats. Oecologia 21:213-222.

Mills, K. E., and J. D. Bever. 1998. Maintenance of diversity within plant communities: soil pathogens as agents of negative feedback. Ecology 79:1595-1601.

Mitchell, C. E., and A. G. Power. 2003. Release of invasive plants from fungal and viral pathogens. Nature 421:625627.

Murdoch, W. W., and C. J. Briggs. 1996. Theory for biological control: recent developments. Ecology 77:2001-2013.

Packer, A., and K. Clay. 2000. Soil pathogens and spatial patterns of seedling mortality in a temperate tree. Nature 404:278-281.

Pimentel, D., L. Lach, R. Zuniga, and D. Morrison. 2000. Environmental and economic costs of nonindigenous species in the United States. BioScience 50:53-65.
Reinhart, K. O. 2003. Mechanisms for invasion by non-native trees-facilitation, ecosystem engineering, and escape from belowground enemies. Dissertation. University of Montana, Missoula, Montana, USA.

Reinhart, K. O., A. Packer, W. H. Van der Putten, and K. Clay. 2003. Plant-soil biota interactions and spatial distribution of black cherry in its native and invasive ranges. Ecology Letters 6:1046-1050.

Scheffer, R. P. 2003. The nature of disease in plants. Cambridge University Press, Cambridge, UK.

Schmucker, T. 1942. The tree species of the northern temperate zone and their distribution. Silvae Orbis 4:406.

Smith, S. E., and D. J. Read. 1997. Mycorrhizal symbiosis. Second edition. Academic Press, San Diego, California, USA.

SPSS. 2000. SPSS version 10. SPSS, Chicago, Illinois, USA. Troelstra, S. R., R. Wagenaar, W. Smant, and B. A. M. Peters. 2001. Interpretation of bioassays in the study of interactions between soil organisms and plants: involvement of nutrient factors. New Phytologist 150:697-706.

Underwood, A. J. 2002. Experiments in ecology. Cambridge University Press, Cambridge, UK.

Usher, M. B. 1988. Biological invasions of nature reserves: a search for generalizations. Biological Conservation 44: 119-135.

Van Der Heijden, M. G. A., J. N. Klironomos, M. Ursic, P. Moutoglis, R. Streitwolf-Engel, T. Boller, A. Wiemken, and I. R. Sanders. 1998. Mycorrhizal fungal diversity determines plant biodiversity, ecosystem variability and productivity. Nature 396:69-72.

Van der Putten, W. H. 2001. Interactions of plants, soil pathogens and their antagonists in natural ecosystems. Pages 285-305 in M. J. Jeger and N. J. Spence, editors. Biotic interactions in plant-pathogen associations. CAB International, New York, New York, USA.

Van der Putten, W. H., C. Van Dijk, and A. M. Peters. 1993. Host-specific soil-borne diseases contribute to succession in foredune vegetation. Nature 362:53-56.

Verkade, S. D. 1991. Efficacy of six VAM fungi with containerized Acer platanoides. Scientia Horticulturae 48:125129.

Vitousek, P. M., L. R. Walker, L. D. Whiteaker, D. MuellerDombois, and P. A. Matson. 1987. Biological invasion by Myrica faya alters ecosystem development in Hawaii. Science 238:802-804.

Vogelsang, K. M. 2002. Plant community composition, soil community structure, and ecosystem function. Dissertation. University of California, Irvine, California, USA.

Westover, K. M., and J. D. Bever. 2001. Mechanisms of plant species coexistence: complementary roles of rhizosphere bacteria and root fungal pathogens. Ecology 82:3285-3294.

Wolfe, L. M. 2002. Why alien invaders succeed: support for the escape-from-enemy hypothesis. American Naturalist 160: $705-711$. 